\title{
Changing blood picture in sickle-cell anaemia from shortly after birth to adolescence
}

\author{
L. R. DAVIS \\ From King's College Hospital, London
}

SYNOPSIS The blood picture of children with sickle-cell anaemia was found to change with age. The changes were most marked in the first year but the mean level of haemoglobin, haemoglobin F, an $\mathbb{\Phi}^{\circ}$ target cells fell until adolescence, and irreversibly sickled cells rose. Reticulocytes, Howell Jolly bodies, and normoblasts altered little after one year. The fall in haemoglobin $\mathrm{F}$ suggested a delayeథ changeover from fetal to adult haemoglobin production. It was concluded that the blood changes ife sickle-cell anaemia were progressive throughout childhood.

Previous authors have shown that some features of the blood in sickle-cell anaemia can vary or be interrelated. Schneider (personal communication) showed that haemoglobin $F$ fell during childhood. Serjeant (1970) showed an inverse relationship between the level of haemoglobin $F$ and the number of irreversibly sickled cells in adults. Davis (1972) showed variations in the number of target cells. Pearson et al (1969) discussed Howell Jolly bodies in relation to functional asplenia. The present study was planned to see how the blood picture of sicklecell anaemia developed from infancy and whether a steady state was reached. In addition to the haemoglobin F, irreversibly sickled cells, target cells, and Howell Jolly bodies, the haemoglobin, reticulocytes, and the presence or absence of normoblasts were considered.

\section{Patients studied}

These were 75 children attending the sickle-cell clinic, who were free from symptoms attributable to sicklecell anaemia and had no intercurrent infections. Elimination of children who were sick meant that any changes that were found might be attributed to age. Capillary samples of blood were collected at yearly intervals or more frequently under the age of 1 year. A total of 174 samples was obtained in three years from children aged 4 days to 16 years. To enable the results on the youngest infants to be compared with the changes in haemoglobin and haemoglobin $F$ found in normal infants of similar age a control population was introduced. This

Received for publication 24 February 1976 consisted of the results of these measurements on 13. infants aged 1 to 7 months. These were hospitas patients and therefore not strictly normal; however? it was considered that their clinical conditions wereo unlikely to affect the results significantly. B̂के haemoglobin F levels on 17 normal cord blo di samples were also included in the control finding

\section{Methods}

Haemoglobin was estimated as cyanmethaemoglobin $\vec{C}$ and haemoglobin $\mathrm{F}$ by the one-minute alkali dena 3 turation method of Singer et al (1951) modified foㄹ the use of capillary samples of blood. The percentages. of irreversibly sickled cells (Jensen et al, 1960) target cells (Davis, 1972), and Howell Jolly bodies were determined by examining 1000 cells on each blood film. The presence or absence of normoblasts. was noted. One thousand cells were also counted te determine the percentage of reticulocytes. T8 minimize personal variation all the counts were done by the author.

\section{Results}

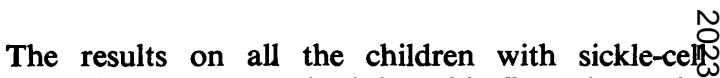
anaemia are summarized in table $I$, and on the control group of infants in table II. The mean of each group of results is plotted against age in the figurec and inspection suggested that the results might be? considered in two parts, namely, below and aboveo 1 year of age.

During the first year there were marked fluctua tions in some of the means. Comparison of the 


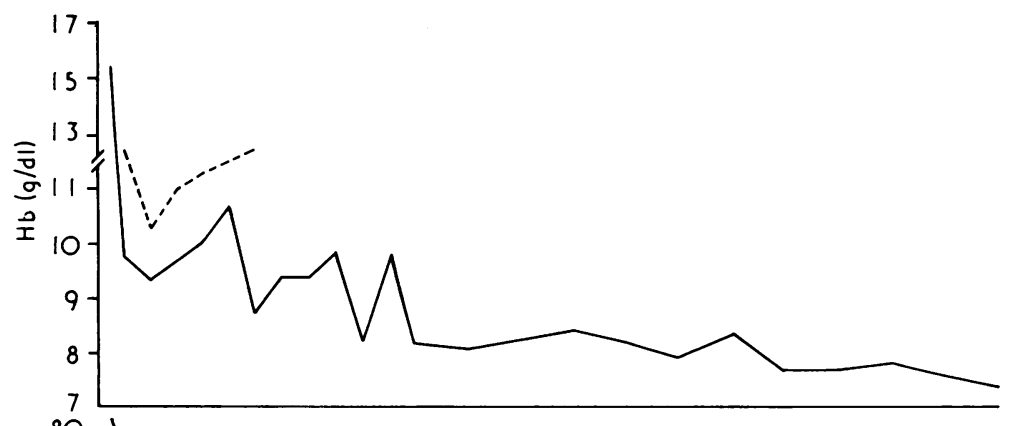

Figure Diagram to illustrate the changes in the mean haemoglobin $(\mathrm{Hb})$, haemoglobin $F(H b F)$,


irreversibly sickled cells (ISC), target cells (TC), Howell Jolly bodies (HJB), and reticulocytes $(R)$. The solid line indicates the mean for infants and children with sickle-cell anaemia and the interrupted line that for the

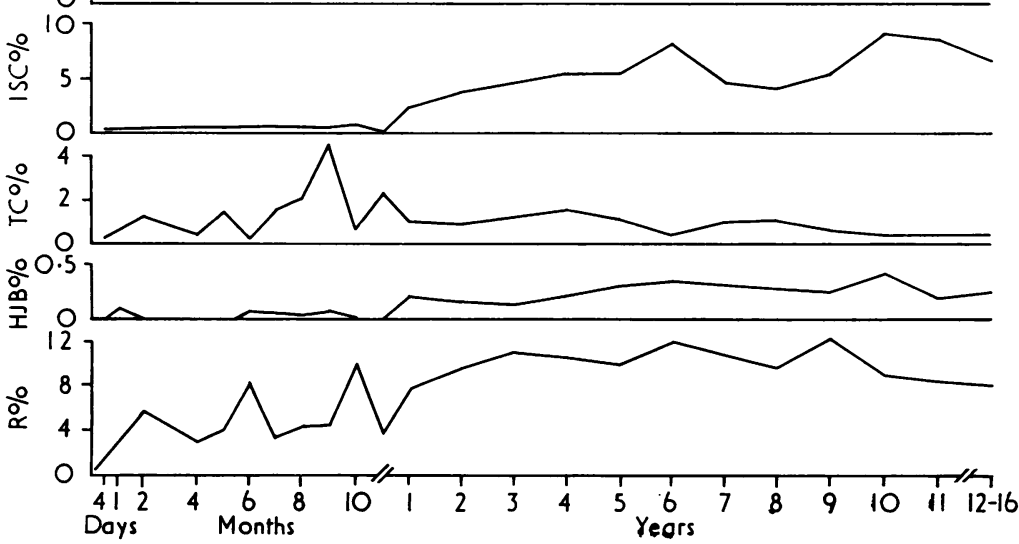
control group of infants.

patients with the controls showed that the former showed a fall and rise in the mean haemoglobin level similar to the latter though the mean reached a lower level and the subsequent rise was less marked. After five months the mean haemoglobin of the patients fell again whereas it would have been maintained in the control infants. The mean haemoglobin $F$ was higher in the patients than in the controls by 1 month of age and was above the range of the controls by 4 months. The fall in the mean haemoglobin $F$ was, therefore, slower in the patients than in the controls. Irreversibly sickled cells and Howell Jolly bodies were uncommon under 1 year of age, but target cells appeared to reach a maximum level at about the end of the first year, and reticulocytes were raised (greater than $2 \%$ ) from 1 month onwards.
Under 1 year normoblasts were more frequently absent than present $(72 \%)$.

From 1 year onwards changes in the means still appeared to be occurring but at a slower rate. It was considered appropriate to examine the regression coefficient for each of the measurements with age and to determine the significance (P) of its standard error. This showed that the haemoglobin level, haemoglobin $F$, and target cells fell significantly from 1 to 16 years $(\mathrm{P}<0.02,<0.001,<0.02$, respectively). On the other hand, the irreversibly sickled cells rose significantly $(\mathrm{P}<0.001)$. There was no significant change in the Howell Jolly bodies or reticulocytes although the means of both were raised. Normoblasts were more commonly present than absent from 1 year onwards $(91 \%)$. 


\begin{tabular}{|c|c|c|c|c|c|c|c|c|c|c|c|c|c|c|c|}
\hline \multirow[t]{2}{*}{ Age } & \multirow[t]{2}{*}{$\begin{array}{l}\text { Number of } \\
\text { results }\end{array}$} & \multicolumn{2}{|c|}{$\begin{array}{l}\text { Haemoglobin } \\
(g / d l)\end{array}$} & \multicolumn{2}{|c|}{$\begin{array}{l}\text { Haemoglobin F } \\
(\%)\end{array}$} & \multicolumn{2}{|c|}{$\begin{array}{l}\text { Reticulocytes } \\
(\%)\end{array}$} & \multicolumn{2}{|c|}{$\begin{array}{l}\text { Irreversibly } \\
\text { sickled cells }(\%)\end{array}$} & \multicolumn{2}{|c|}{$\begin{array}{l}\text { Target cells } \\
(\%)\end{array}$} & \multicolumn{2}{|c|}{$\begin{array}{l}\text { Howell Jolly } \\
\text { bodies }(\%)\end{array}$} & \multicolumn{2}{|c|}{ Normoblasts } \\
\hline & & Mean & $S D$ & Mean & $S D$ & Mean & $S D$ & Mean & $S D$ & Mean & $S D$ & Mean & $S D$ & Present & Abs \\
\hline $4 d$ & 1 & $(15 \cdot 4)$ & - & (81) & - & $(0 \cdot 1)$ & - & $(0 \cdot 0)$ & - & $(0.2)$ & - & $(0 \cdot 0)$ & - & 0 & 1 \\
\hline $1 \mathrm{mth}$ & 5 & $9 \cdot 78$ & 1.49 & $64 \cdot 40$ & 4.96 & $2 \cdot 82$ & $1 \cdot 12$ & 0.10 & 0.11 & 0.68 & 1.02 & 0.06 & 0.42 & 2 & 3 \\
\hline $2 \mathrm{mth}$ & 6 & $9 \cdot 30$ & 0.71 & $44 \cdot 67$ & $4 \cdot 86$ & $5 \cdot 27$ & 1.45 & 0.33 & 0.20 & 1.07 & $1 \cdot 26$ & 0.00 & - & 1 & 5 \\
\hline $4 \mathrm{mth}$ & 2 & $10 \cdot 00$ & $1 \cdot 20$ & $34 \cdot 00$ & $2 \cdot 00$ & $3 \cdot 10$ & $1 \cdot 30$ & 0.15 & $0 \cdot 15$ & 0.40 & 0.40 & 0.00 & - & 0 & 2 \\
\hline $5 \mathrm{mth}$ & 4 & $10 \cdot 60$ & 0.30 & $29 \cdot 50$ & 2.06 & $4 \cdot 25$ & $1 \cdot 64$ & 0.48 & 0.39 & 1.45 & $1 \cdot 23$ & 0.00 & - & 1 & 3 \\
\hline $6 \mathrm{mth}$ & 4 & 8.65 & $1 \cdot 02$ & $24 \cdot 75$ & 3.49 & $8 \cdot 55$ & $4 \cdot 88$ & 0.68 & 0.54 & 0.25 & 0.29 & 0.03 & 0.49 & 1 & 3 \\
\hline $7 \mathrm{mth}$ & 3 & $9 \cdot 30$ & 0.50 & 22.67 & $2 \cdot 84$ & 3.40 & $1 \cdot 10$ & 0.60 & 0.77 & 1.63 & 0.66 & 0.03 & 0.05 & 0 & 3 \\
\hline $8 \mathrm{mth}$ & 3 & $9 \cdot 30$ & $1 \cdot 10$ & $17 \cdot 67$ & $1 \cdot 18$ & $4 \cdot 23$ & $1 \cdot 68$ & 0.43 & 0.54 & $2 \cdot 07$ & 0.62 & 0.03 & 0.05 & 2 & 1 \\
\hline $9 \mathrm{mth}$ & 4 & $9 \cdot 85$ & 0.37 & $18 \cdot 25$ & $4 \cdot 02$ & $4 \cdot 40$ & $2 \cdot 30$ & 0.45 & 0.15 & $4 \cdot 90$ & $2 \cdot 30$ & 0.05 & 0.05 & 1 & 3 \\
\hline $10 \mathrm{mth}$ & 2 & $8 \cdot 15$ & 0.75 & $21 \cdot 50$ & 8.50 & $10 \cdot 35$ & $4 \cdot 35$ & 0.90 & 0.50 & 0.55 & 0.79 & 0.00 & - & 2 & 0 \\
\hline $11 \mathrm{mth}$ & 3 & $9 \cdot 77$ & 0.78 & 16.67 & $4 \cdot 48$ & $3 \cdot 27$ & 0.68 & $0 \cdot 17$ & $0 \cdot 17$ & 2.43 & $1 \cdot 18$ & 0.00 & - & 0 & 3 \\
\hline $1 \mathrm{yr}$ & 16 & $8 \cdot 07$ & $1 \cdot 00$ & 13.80 & $6 \cdot 20$ & $7 \cdot 65$ & 3.90 & $2 \cdot 44$ & $3 \cdot 20$ & 1.04 & 1.03 & 0.22 & 0.32 & 10 & 6 \\
\hline $2 \mathrm{yr}$ & 14 & $7 \cdot 99$ & $1 \cdot 30$ & $9 \cdot 36$ & $6 \cdot 16$ & $9 \cdot 61$ & $3 \cdot 79$ & 3.79 & $2 \cdot 32$ & 0.93 & 0.98 & $0 \cdot 17$ & 0.12 & 14 & 0 \\
\hline $3 \mathrm{yr}$ & 11 & $8 \cdot 18$ & 0.90 & $9 \cdot 00$ & $3 \cdot 96$ & $10 \cdot 54$ & $3 \cdot 62$ & $4 \cdot 62$ & $2 \cdot 13$ & $1 \cdot 34$ & $1 \cdot 49$ & $0 \cdot 16$ & $0 \cdot 11$ & 11 & 0 \\
\hline $4 \mathrm{yr}$ & 12 & $8 \cdot 35$ & $1 \cdot 28$ & $8 \cdot 67$ & 5.00 & 10.49 & 4.04 & $5 \cdot 46$ & $3 \cdot 36$ & $1 \cdot 58$ & 1.68 & 0.21 & $0 \cdot 16$ & 12 & 0 \\
\hline 5 yr & 8 & $8 \cdot 18$ & 0.67 & $5 \cdot 88$ & $2 \cdot 93$ & $9 \cdot 78$ & $3 \cdot 77$ & $5 \cdot 43$ & $2 \cdot 75$ & 1.08 & 0.91 & 0.31 & 0.21 & 7 & 1 \\
\hline $6 \mathrm{yr}$ & 14 & $7 \cdot 85$ & $1 \cdot 27$ & $5 \cdot 64$ & $4 \cdot 21$ & $11 \cdot 51$ & $4 \cdot 18$ & $8 \cdot 36$ & 5.45 & 0.39 & 0.35 & 0.34 & 0.36 & 14 & 0 \\
\hline $7 \mathrm{yr}$ & 15 & $8 \cdot 26$ & 0.79 & $9 \cdot 20$ & 5.85 & 10.66 & $3 \cdot 13$ & $4 \cdot 70$ & $3 \cdot 51$ & 0.95 & 0.76 & 0.31 & $0 \cdot 30$ & 14 & 1 \\
\hline $8 \mathrm{yr}$ & 11 & $7 \cdot 59$ & $1 \cdot 39$ & $8 \cdot 73$ & $6 \cdot 24$ & $9 \cdot 63$ & 6.58 & $4 \cdot 65$ & 3.88 & 1.03 & $1 \cdot 29$ & 0.28 & 0.16 & 11 & 0 \\
\hline $9 \mathrm{yr}$ & 12 & $7 \cdot 58$ & 1.00 & $7 \cdot 67$ & $5 \cdot 35$ & $12 \cdot 33$ & $5 \cdot 53$ & 5.43 & $4 \cdot 15$ & 0.59 & 0.72 & $0 \cdot 28$ & $0 \cdot 17$ & 12 & 0 \\
\hline $10 \mathrm{yr}$ & 8 & $7 \cdot 70$ & 1.07 & $6 \cdot 38$ & $4 \cdot 26$ & $7 \cdot 90$ & $2 \cdot 17$ & $9 \cdot 24$ & $5 \cdot 61$ & 0.49 & 0.63 & 0.43 & 0.20 & 7 & 1 \\
\hline $11 \mathrm{yr}$ & 8 & $7 \cdot 54$ & 1.08 & $6 \cdot 13$ & $2 \cdot 61$ & $8 \cdot 38$ & $4 \cdot 18$ & $9 \cdot 04$ & $6 \cdot 71$ & 0.46 & 0.38 & $0 \cdot 18$ & 0.12 & 7 & 1 \\
\hline $12-16$ yr & 8 & $7 \cdot 29$ & 0.62 & $5 \cdot 13$ & 1.89 & $7 \cdot 50$ & $4 \cdot 06$ & $7 \cdot 14$ & $4 \cdot 01$ & 0.41 & 0.39 & $0 \cdot 28$ & $0 \cdot 25$ & 6 & 2 \\
\hline
\end{tabular}

Table I Findings in cases of sickle-cell anaemia

SD $=$ standard deviation. Results in parentheses indicate single case aged 4 days.

\begin{tabular}{|c|c|c|c|c|c|}
\hline \multirow{2}{*}{$\begin{array}{l}\text { Age } \\
\text { (mth) }\end{array}$} & \multirow{2}{*}{$\begin{array}{l}\text { No. of } \\
\text { results }\end{array}$} & \multicolumn{2}{|c|}{ Haemoglobin $(\mathrm{g} / \mathrm{dl})$} & \multicolumn{2}{|c|}{ Haemoglobin $F(\%)$} \\
\hline & & Mean & $S D$ & Mean & $S D$ \\
\hline Cord blood & 17 & - & - & $75 \cdot 24$ & 6.89 \\
\hline 1 & 26 & 11.64 & 1.84 & 56.81 & $11 \cdot 50$ \\
\hline 2 & 28 & 10.39 & 1.22 & $26 \cdot 68$ & $16 \cdot 29$ \\
\hline 3 & 26 & 10.87 & 1.07 & 13.69 & 6.61 \\
\hline 4 & 27 & 11.22 & 1.05 & $7 \cdot 78$ & 5.84 \\
\hline $5-7$ & 27 & 11.50 & 1.33 & 3.96 & $2 \cdot 18$ \\
\hline
\end{tabular}

Table II Findings in control group of infants

SD $=$ standard deviation .

\section{Discussion}

The full blood picture of sickle-cell anaemia did not always appear before the age of 1 year. Under this age the blood showed a mixed picture in which the normal changes found in the first few months of life were more marked and were modified by the gradual emergence of a haemolytic picture. That haemolysis was present from an early stage was indicated by the presence of a raised mean reticulocyte count (greater than $2 \%$ ). After 1 year the condition still progressed with a fall in the mean haemoglobin level, a rise in the irreversibly sickled cells, and a fall in the target cells. A steady state was not achieved during childhood. The level of haemoglobin F continued to fall until puberty, which confirmed the finding of Schneider (personal communication). Thus any clinical advantage the presence of haemoglobin $F$ might confer on the patient (Jackson et al, 1961) would not be lasting, and it might be suggested that in sickle-cell anaemia there was a prolongation of the normal changeover from fetal to adult haemoglobin production (in this case haemoglobin S), which might not proceed to completion during childhood.

Serjeant (1970) showed that high levels of irreversibly sickled cells were associated with low levels of haemoglobin $\mathrm{F}$ and vice versa. He excluded children from his studies because Schneider had reported that the most rapid fall in haemoglobin $F$ occurred during childhood. The present study showed that the inverse relationship between the level of haemoglobin $F$ and the percentage of irreversibly sickled cells applied to children aged 1 to 16 years. There was a very significant negative correlation $(P<0.001)$ which held even when the effects of age were eliminated by a partial correlation coefficient.

Target cells were found to decrease in number with increasing age. This was rather surprising because an increase might be expected as the result of autosplenectomy during childhood. They showed a significant negative correlation coefficient with irreversibly sickled cells, but this disappeared when allowance was made for the effect of age. They were also negatively correlated with the percentage of reticulocytes, and this even held when allowance was 
made for age $(P<0.05)$. It had been suggested (Davis, 1972) that the occasional target cells seen in normal films might be young cells which had just matured from reticulocytes because polychromatic cells (reticulocytes) not infrequently showed a target appearance. This did not appear to be the case in sickle-cell anaemia as the correlation was negative.

Reticulocytes and Howell Jolly bodies might be expected to rise with age as a result of autosplenectomy. That reticulocytes did not was probably a reflection of the maximum activity of the bone marrow in a chronic haemolytic anaemia. The findings of raised Howell Jolly bodies from the age of 1 year onwards when many of the children would still have had enlarged spleens was presumably illustrative of the functional asplenia described by Pearson et al (1969). In older children the presence of Howell Jolly bodies probably did indicate autosplenectomy. It should be noted that $19 \%$ of the results on children over the age of 1 year showed no Howell Jolly bodies, and in individual cases they were not necessarily present at every examination. Thus it seemed likely that splenic activity varied from time to time.

No attempt was made to enumerate the number of normoblasts present; it was merely recorded whether they were present or absent from the film. They were uncommon under the age of 1 year and very com- mon over that age. Their presence or absence did not appear to be particularly associated with any of the other features which were studied.

I wish to thank the laboratory staff for their assistance, Dr K. G. A. Clark for reading the manuscript, Mr K. C. Ryan for assistance with the statistics, and Professor C. E. Stroud whose patients were studied. The study was started under a research grant from the joint research fund of King's College Hospital and Medical School.

\section{References}

Davis, L. R. (1972). Target cells in haemoglobinopathies. J. clin. Path., 25, 169-170.

Jackson, J. F., Odom, J. L., and Bell, W. N. (1961). Amelioration of sickle cell disease by persistent fetal hemoglobin. $J$. Amer. med. Ass., 177, 867-869.

Jensen, W. N., Rucknagel, D. L., and Taylor, W. J. (1960). In vivo study of the sickle cell phenomenon. J. Lab. clin. Med., 56, 854-865.

Pearson, H. A., Spencer, R. P., and Cornelius, E. A. (1969). Functional asplenia in sickle-cell anemia. New Engl.J. Med., 281, 923-926.

Schneider, R. G. (Personal communication).

Serjeant, G. R. (1970). Irreversibly sickled cells and splenomegaly in sickle cell anaemia. Brit.J. Haemat., 19, 635-641.

Singer, K., Chernoff, A. I., and Singer, L. (1951). Studies on abnormal hemoglobins. I. Their demonstration in sickle cell anemia and other hematologic disorders by means of alkali denaturation. Blood, 6, 413-428. 